ISSN: 2146-3042

DOI:

\title{
Covid-19’un Ara Dönem Finansal Raporlama Üzerindeki Etkileri: Havacılık Ve İlaç Sektörü Üzerine Bir Araştırma*
}

\author{
Tuğba Dölen** \\ Serap S. Yanık*** \\ Yıldız Ayanoğlu ****
}

\begin{abstract}
ÖZET
Covid-19 nedeniyle havacılı, konaklama, eğlence gibi belirli sektörlerde faaliyet gösteren şirketler olumsuz etkilenmiş, gıda, lojistik ve ilaç gibi bazı sektörlerde ise iş hacmi birkaç katına çıkmıştır. Her iki durumda da şirketlerin ara dönem finansal tablolarında bir önceki yılın aynı ara dönemine göre farklılıkların çıkması beklenen bir sonuçtur. Çalışmada bu farklılıkların tespit edilmesi amacıyla BiST 100'de faaliyet gösteren salgından olumlu etkilenen olarak ilaç sektöründeki üç işletme, olumsuz etkilenen olarak ise havacılık sektöründeki üç işletme araştırmaya dahil edilmiştir. Söz konusu sektörlerdeki işletmelerin Haziran - Eylül 2020 ara dönem finansal tabloları bir önceki yılın aynı dönemlerindeki finansal tabloları ile karş̧laş̧ırılarak Covid-19'un etkileri ve dipnotlara eklenen yeni bilgiler ortaya konmaya çalışılmıştır. Elde edilen sonuçlara göre; her iki sektörde de nakit bulundurma pozisyonları artmıştır. Havacılık sektöründe kargo taşımacılığının, ilaç sektöründe ise beslenme ve metabolizma segmentindeki ilaç satışlarının arttığı görülmüşür. Havacılık sektöründe Covid- 19 salgınının şirketlerin faaliyetlerine etkileri başlıklı dipnot açılklamalarının bulunduğu, ilaç sektöründe ise yeterli açılklamaların yapılmadığı dikkat çekmiştir.
\end{abstract}

Anahtar Kelimeler: Ara Dönem Finansal Raporlama, Covid-19, Covid-19’un Olası Etkileri

JEL Sinıflandırması: M40, M41.

\section{Covid-19's Effects on Interim Financial Reporting: A Research on Aviation and} Pharmaceutical Industry

\section{ABSTRACT}

Due to Covid-19, companies operating in certain sectors such as aviation, accommodation, and entertainment have been negatively affected, while business volume has increased several times in some sectors such as food, logistics and medicine. In both cases, it is expected that differences in the interim financial statements of the companies will emerge from the same interim period of the previous year. In order to identify these differences, the study included three businesses in the pharmaceutical industry and three businesses in the aviation industry, which were affected positively by the outbreak in the BIST 100, in order to identify these differences. We tried to compare the interim financial statements of the businesses in these sectors in June-September 2020 with those of the same period of the previous year and to reveal the effects of Covid-19 and new information added to the footnotes. According to the results obtained: cash possession positions in both sectors have increased. In the aviation industry, cargo transportation and pharmaceutical sales in the nutrition and metabolism segment have increased. It was noted that in the aviation industry, the Covid 19 epidemic had footnote explanations on the effects of companies on their operations, and the pharmaceutical industry did not provide adequate explanations.

Keywords: Interim Financial Reporting, Covid-19, Potential Effects of Covid-19.

Jel Classification: M40, M41

\footnotetext{
* Bu makale, 23-25 Nisan 2021 tarihleri arasında gerçekleștirilen VI. Uluslararası Muhasebe ve Finans Sempozyumunda bildiri olarak sunulmuştur.

Makale Gönderim Tarihi: 05.06.2021, Makale Kabul Tarihi: 20.06.2021, Makale Türü: Nicel Araştırms

${ }_{* *}^{*}$ Dr. Öğr. Üyesi, Ankara Hacı Bayram Veli Üniversitesi, Polatlı Sosyal Bilimler Meslek Yüksekokulu, tugba.dolen@hbv.edu.tr, ORCID: 0000-0003-3230-0318.

*** Prof. Dr., Ankara Hacı Bayram Veli Üniversitesi, İktisadi ve İdari Bilimler Fakültesi, serap.yanik@hbv.edu.tr, ORCID: 0000-0001-7525-8717.

**** Prof. Dr., Ankara Hacı Bayram Veli Üniversitesi, İktisadi ve İdari Bilimler Fakültesi, yildiz.ayanoglu@hbv.edu.tr, ORCID: 0000-0002-1024-2105.
} 


\section{GíRiş}

Finansal bilgi okuyucularının kriz ve salgın gibi global etkisi olan olayların işletmeler üzerindeki sonuçlarını doğru okuyup analiz edebilmesi için tablolardaki dipnot açıklamalarını ve işletmenin sürekliliğini devam ettirme kabiliyetini değerlendirebilmeleri gerekir. Ayrıca muhasebe bilgi kullanıcıları bu ortamda her zamankinden daha fazla finansal bilgiye ihtiyaç duymaktadır. $\mathrm{Bu}$ nedenle muhasebe otoriteleri, Covid-19'un finansal etkilerinin tablolara yansitılmasında dikkate alınması gereken finansal raporlama gereksinimleri hakkında tavsiye niteliğinde açıklamalarda bulunmuşlardır.

Avrupa Menkul Kiymetler ve Piyasalar Kurumu 2020 Mayıs ayı sonunda borsaya kayıtlı şirketlerin Covid-19 salgınının finansal raporlar üzerindeki etkilerini ele alan kamuoyu açıklaması yapmıştır. Yapılan şeffaflık çağrısı; ara dönem finansal raporlamada özellikle önemli belirsizlikler ve riskler, süreklilik, finansal olmayan varlıkların değer düşüklüğü ile ilgili olarak Covid-19'un etkileriyle ilgili yeterince bilgilendirme yapılmasını içermektedir (ESMA, 2020).

Uluslararası Muhasebe Standartları Kurulu, Covid-19 salgınında Uluslararası Muhasebe (Finansal Raporlama) Standartlarının uygulanması ile ilgili açıklamalarda bulunmuştur. UMS 34 Ara Dönem Finansal Raporlama Standardı gereği, işletmelerin önemli değişiklikleri ve bu değişikliklerin finansal tablolar üzerindeki etkisini önceki dönemde yıllık olarak raporlananlara kıyasla açıklamaları gerektiği vurgulanmıştır. Ayrıca ara dönem finansal raporlarda özellikle finansal ve finansal olmayan varlıkların değer düşüklügü̆, belirsizlik ve gerçeğe uygun değer ölçümleri ile ilgili önemli değişiklikleri açıklaması gerektiği ifade edilmiştir (IASB, 2020).

Uluslararası Muhasebeciler Federasyonu, Covid-19'un finansal raporlamaya etkileri üzerine yayınladığı rehberde; süreklilik esasına göre faaliyet gösterme kabiliyeti konusunda şüpheler oluşturan önemli belirsizliklerin finansal tablolarda açıklanması gerektiğini ifade etmiştir. Ayrıca ara dönem finansal raporlamada; finansal araçlar ve finansal olmayan varlıkların değer düşüklüğü, beklenen kredi zararları ve ertelenmiş vergi varlıklarının geri kazanılabilirliği ile ilgili açıklamaların yapılması tavsiye edilmiştir (IFAC, 2020).

Çalışmada, öncelikle TMS 34 Ara Dönem Finansal Raporlama Standardı dikkate alınarak Covid-19'un ara dönem finansal raporlarına olası etkisi açıklanmıştır. Daha sonra BİST 100 endeksinde havacılık ve ilaç sektörlerinde faaliyet gösteren şirketlerin 30.06.2019 ve 30.06.2020 ile 30.09.2019 ve 30.09.2020 tarihlerindeki ara dönem finansal raporlar1 belirlenen değişkenler dikkate alınarak karşılaştırılmıştır. Bu sektörlerde faaliyet gösteren şirketlerin ara dönem finansal raporlarındaki farklılıkları ile finansal bilgilerin güncellenme durumları ortaya konulmuş ve küresel salgından dolayı tablolara, dipnotlara eklenen yeni bilgiler karşılaştırmalı olarak değerlendirilmiştir.

\section{COVID-19’UN ARA DÖNEM FINANSAL RAPORLARINA OLASI ETKISİ}

Muhasebe sistemi, işletmelerin her bir ekonomik faaliyet sonucunu ve finansal durumunu anında göstermelidir. İşletme ile ilgili finansal bilgilere ihtiyaç duyan finansal bilgi kullanıcıları dönem sonundaki kapanış işlemlerini beklemeden bilgi sahibi olmayı istemektedir. Zamanında yapılan ve güvenilir bir ara dönem raporlama; finansal bilgi 
kullanıcılarının işletmenin gelir ve nakit akışı yaratma kapasitesi ile finansal durumunu, finansal performansını ve likiditesini daha iyi anlamasını sağlamaktadır (TMS 34:3).

Ara dönem finansal raporlamanın asgari içeriğinin tanımlanması ve ara döneme ilişkin özet veya ayrıntılı finansal tablolardaki muhasebeleştirme ve ölçme ilkelerini belirlemek (TMS 34:3) amaciyla TMS 34 Ara Dönem Finansal Raporlama Standard1 31/12/2005 tarihinden sonra başlayan hesap dönemleri için uygulanmak üzere ilk olarak 02/02/2006 tarihinde yayımlanmıştır.

Standart, hangi işletmelerin ara dönem finansal rapor hazırlayacağını, hangi sıklıkta veya ara dönemden sonra ne kadar kısa bir zamanda yayınlaması gerektiği hususlarını düzenlemez. Bununla birlikte SPK, borsa ve muhasebe düzenleyici kuruluşları özellikle borçlanma ve hisse senetleri halka arz edilmiş işletmelerin ara dönem raporlama yapmasını öngörebilir. Türkiye Muhasebe Standartları Kurulu halka açık işletmelerin TMS 34 çerçevesinde belirlenen muhasebeleştirme, ölçme ve açıklama ilkelerine uygun olarak ara dönem finansal raporlama yapılmasını teşvik eder ve en azından 1.altı aylık dönemde bu tabloları hazırlamasını ve izleyen 60 gün içinde sunmasını ister. (TMS 34:1).

Dünya genelinde eğer bir işletme özel hesap dönemine tabii değil ise üçer aylık dönemlerde finansal tablo hazırlamaktadır. Ülkemizde de hisse senetleri borsada işlem gören şirketler, bankalar, aracı kurumlar, menkul kıymet yatırım fonları, emeklilik yatırım şirketleri ve EPDK denetiminde olan şirketler gibi işletmeler üç ay arayla finansal tablo düzenlemektedirler. Ayrıca; birleşme, bölünme, devir ve tasfiye gibi özel durumlarda da TMS 34 uygulanmaktadir.

Ara dönem finansal raporlama ile en son yıllık finansal tablo setinde yer alan finansal bilgilerin güncellenmesi amaçlanır. $\mathrm{Bu}$ çerçevede, ara dönemde yeni faaliyetler, olaylar ve durumlar üzerine odaklanılır ve daha önce raporlanan finansal bilgilerin tekrarından kaçınılır (TMS 34:6). En son y1llik raporlama döneminden sonra meydana gelen önemli nitelikteki değişiklikler ara dönem finansal raporlara dâhil edilir. Böylece yıllık finansal raporda sunulan ilgili bilgiler de güncellenmiş olur.

Önemli hesap kalemleri, finansal olaylar ve diğer hususların ara dönem finansal tablolarda yer alması zorunludur. Standartta önemli bulunması durumunda, açıklama yapılması gereken bazı olaylar ve işlemler sıralanmıştır. Ancak standartta belirtilen önemlilik kavramı ile ilgili mevzuatta ve literatürde nitel bir açıklama bulunmamaktadır. Buna göre; bilginin saklanması, hatalı olması veya verilmemesi durumunda finansal tabloların birincil kullanıcıların bu tablolara dayanarak verdikleri kararları etkileyebileceği varsayılabilirse, bilgi önemlidir (TMS 8:2).

TMS 34 genel olarak tüm işlem ve olayların her bir ara dönemin ayrı ve bağımsız bir dönem gibi kabul edilerek muhasebeleştirilmesini ve ölçülmesini gerektirir ve ara dönem özet finansal tabloları en son yıllık raporlama döneminden itibaren yapılan değişiklere odaklanır. Dolayısıyla, küresel salgın döneminde şirketlerin finansal ve ekonomik durumundaki değişiklikleri daha önceki ara dönem finansal tablolarda yer almayan açıklamaları içerecektir, bu da ara finansal tabloların hem kendisinden önceki ara dönemi hem de önceki yılın aynı ara dönemi ile karşılaştırabilirliğini azaltacaktır. 
Covid-19'un finansal tablolardaki bazı kalemleri ve dipnot bilgilerini etkileyeceği öngörülmektedir. Dünya Sağlık Örgütü tarafından 11.03.2020 tarihinde pandemi ilan edilmesinden dolayı 2020 yılı Haziran ve Eylül ara dönem finansal tablolarında, 2019 ara dönem finansal tablolarında yer almayan kalem ve açıklamalar olabilir. Bunlara örnek olarak aşağıdakiler verilebilir (KPMG: 2020’den faydalanılarak yorumlanmıştır):

- Vergi İndirim ve Avantajları: Salgın nedeniyle vergi düzenlemelerinde yatırım, Ar-Ge gibi harcamalara bağlı olarak, ortaya çıkan vergi yükümlüklerine karşı mükelleflere vergi indirimi veya farklı bir vergi avantajı sağlanabilir. Bu tür avantajlar da meydana geldikleri ara dönemde finansal tablolara yansitılırlar.

- Ertelenmiş Vergi Varlıklarının Geri Kazanabilirliği ile Mali Zararların ve Vergi Indirimlerinin Geriye veya İleriye Aktarılması: Yaşanan bu salgın süreci, işletmelerin gelecekte elde edebilecekleri vergilendirilebilir karı ve yeterli olup olmayacağını öngörmeyi zorlaştırabilir. Aynı koşul kullanılmayan vergi indirimleri ve mahsup edilemeyen mali zararlar için de geçerlidir.

- $\quad$ Çalışanlara sağlanan faydalar ve işveren yükümlülükleri: Mevcut pandemi koşullarında çalışanların yarı zamanlı çalışması kıdem tazminatı karşılıklarının revizyonunu gerektirmektedir.

- $\quad$ Stoklar: Mevcut küresel salgın ortamında ara dönem raporlama tarihinde bazı sektörlerde net gerçekleşebilir değer tahminlerinin sağlıklı bir şekilde yapılması tam olarak mümkün olamayacaktır. İşletmelerin stoklarını net gerçekleşebilir değere indirgemesi veya değer düşüklüğü zararlarının iptallerini ara dönem finansal tablolarında açıklamaları gerekmektedir.

Varlıklarda Değer Azalışı: Ara dönem raporlama tarihinde varlıklarda değer düşüklüğüne ilişkin göstergelerin gözden geçirilmesi gerekir ve işletme önemli değer azalış1 göstergelerinin varlığ 1 durumunda dönem sonu raporlama tarihinde olduğu gibi değerlendirir. Önemli tutarlarda değer düşüklüğünün muhasebeleştirilmesi halinde işletme ara dönem finansal raporlarında buna ilişkin açıklama yaparak, yıl sonu raporlarındaki bilgilerin güncellenmesini sağlar.

- Maddi Duran Varlıklar ve Maddi Olmayan Duran Varlıklar: TMS 16 Maddi Duran Varlıklar Standardına göre en azından her bir hesap döneminin sonunda maddi duran varlıkların kalıntı değeri ve faydalı ömrü gözden geçirilmelidir. Diğer taraftan maddi olmayan duran varlıkların muhasebeleştirme ve raporlama kriterlerinin ara dönemde de yıl sonu raporlamasında olduğu gibi uygulanması gerekir. Küresel salgın koşulları dikkate alındığında söz konusu varlıklar için işletmenin kullanım veya elde tutma stratejisinin değişmesi olasıdır, satın alma yerine kiralama tercih edilebilir. Böyle bir durumda ara dönemlerde de tahminlerin yeniden gözden geçirilmesi ve ilgili kayıtların yapılması gerekir.

- Amortisman ve İtfa Payları: Salgın döneminde üretim faaliyeti düştüğü için satılacak maddi duran varlıklar, işletmede mevcut olsalar bile Satış Amaçlı Elde Tutulan Duran Varlıklara alındıysa, amortisman hesaplanmayacaktır.

- Klsa Vade - Uzun Vade (Cari - Cari Olmayan) Sinıflandırması: Borçların zamanında ödenmesinde temerrüde düşülmesi veya raporlama dönemi içinde feragat edilmemiş bir borç anlaşmasının koşullarının yerine getirilmemesi ara dönem finansal raporlarında açıklamayı gerektirmektedir.

- Ek Finansal Tablo Kalemleri: Salgın döneminde ara dönem finansal tablolarında ek kalemlere özellikle de olağandışı nitelikteki kalemlere yer verilmesi işletme yönetimi tarafından değerlendirilmelidir. Örneğin; devlet teşvikleri gibi süreklilik arz etmeyen kalemlerin niteliği ve tutarı açıklanmalıdır. 
- Düzeltme Gerektiren ve Düzeltme Gerektirmeyen Olay Ayrımı: Düzeltme gerektiren ve düzeltme gerektirmeyen olay ayrımı yönetimin muhakemesine bırakılmıştır. Ancak ara dönem raporlama tarihinden sonra ortaya çıkan ve bu ara dönem tablolarına yansıtılmayan olaylar mutlaka açıklanır. Diğer taraftan TMS 8'de belirtilenlere uygun olarak muhasebe politikası değişikliği yapıldığında bunun finansal tablolara yansıtılması ve geriye doğru düzeltme yapılması gerekir. Cari yılın önceki ara dönem tabloları ile önceki yılın karşılaştırılmalı ara dönem tabloları düzeltilir.

- Gerçeğe Uygun Değerin Belirlenmesi: Salgın koşullarında, önemli düzeyde gözlemlenebilir olmayan giderlerin kullanıldığ bir değerlemenin yapılması, zor ve maliyetli olan değerleme işlemini daha da zor bir hale getirecektir. Kullanım hakkı, yeniden değerleme modeliyle değerlenen maddi duran varlıklar, bazı yatırım amaçlı gayrimenkuller gibi varlıklar için önceki yıllın dönem sonu bakiyeleri baz alınarak tahminlerin yapılması da uygun olmayabilir.

İsletmenin Sürekliliği: Küresel salgın ve global kriz dönemlerinde yönetimin işletmenin sürekliliğine ilişkin değerlendirmesi önemli ölçüde etkilenebilir. Yıllık finansal tabloların hazırlanması esnasında yapılan süreklilik değerlendirmesinde geçerli olan hususlar ara dönem finansal tablolarında farklılaşmış olabilir.

- Karşılaştırılabilirliğin Azalması ve Finansal Analize Etkisi: İşletmenin bulunduğu sektöre göre değişkenlik göstermekle birlikte cari yılın finansal tabloları önceki yılın ara dönem finansal tablo kalemlerinden tutar olarak ciddi ölçüde farklılaşabilir. $\mathrm{Bu}$ durum tüm finansal tablo analiz tekniklerine yansıyacaktır.

- Kira imtiyazları: TFRS 16 Kiralamalar Standardında Covid-19 salgını nedeniyle 1 Haziran 2020 tarihinde veya bu tarihten sonra başlayan yıllık raporlama dönemlerinde geçerli olmak üzere kira ödemelerinde kiracılara bazı imtiyazlar sağlamıştır.

- Devlet Teşvikleri ve Yardımlar: Devlet tarafından sağlanan teşvik ve yardımlardan yararlanan şirketlerin, ara dönem finansal tablo dipnotlarında bu durumu açıklamaları beklenmektedir.

\section{LITERATÜR TARAMASI}

Covid-19'un ara dönem finansal raporlama sürecine etkisiyle ilgili yapılan çalışmaların bir kısmı denetim firmalarından olan Ernst\&Young, KPMG, PWC ve GrantThornton tarafindan yapılan çalışmalardan oluşmaktadır. Bu çalışmalar ile birlikte literatürde, araştırmamızla ilgili olan diğer eserler aşağıda özetlenmiştir.

Cavlak (2020) çalışmasında; Covid-19'un ekonomik etkilerinin finansal raporlarda nasıl yer aldığını ve hangi başlıklar altında bilgilendirme yapıldığını belirlemek amacıyla BİST 100 endeksinde işlem gören şirketlerin 31.03.2020 tarihli ara dönem finansal raporlarını içerik analizi ile değerlendirmiştir. Buna göre; Covid-19 ile ilgili açıklamaların en çok raporlama döneminden sonraki olaylar dipnotunda yer aldığını ve en detaylı açıklamaların bankalar tarafından yapıldığı tespit etmiştir. Finansal raporlar için önem arz eden işletmenin sürekliliği, muhasebe tahmin ve varsayımları ile muhasebe politikaları konularına çok az yer verildiğini ortaya koymuştur.

Demir (2020), Covid-19'un TFRS kapsamındaki finansal raporlamaya olan etkilerini ve TMS kapsamında denetçinin dikkate alması gereken hususlarını değerlendirdiği çalışmasında, finansal tabloların sunumuna ilişkin ilkelerle ilgili standartların, Covid-19 salgını kapsamında nasıl değerlendirilmesi gerektiğini açıklamıştır. Salgın nedeniyle ara 
dönem raporlamada geçmiş dönem raporlamalarından daha fazla açıklama yapılması gereği vurgulanmıştır.

Boydaş Hazar (2020) çalışmasında Covid-19 salgınından kaynaklanan değişikliklerin bazı muhasebe standartlarına işletmenin sürekliliği varsayımına etkisini incelemiştir. Araştırmasının sonucunda TFRS 13 Gerçeğe Uygun Değer Ölçümü, TFRS 15 Müşteri Sözleşmelerinden Hasılat, TMS 2 Stoklar, TMS 16 Maddi Duran Varlıklar ve TMS 36 Varlıklarda Değer Düşüklüğü standartlarının tam ve doğru olarak uygulanmasının finansal tabloların hazırlanışındaki önemi vurgulanmıştır.

Jabbar v.d. (2020), Japonya'da Covid-19'un Uluslararası Finansal Raporlama Standartları (FRS) üzerindeki etkilerini değerlendirdikleri çalışmalarında, salgının finansal raporlamayı etkilediğini ve şirketlerin ara dönem finansal raporlamada zorluk çektiklerini ortaya koymuşlardır. Çalışmada, Covid- 19 nedeniyle, Japonya'da finansal raporlama zamanlamasıyla ilgili düzenleme yapıldığı ve ara dönem finansal raporlamanın önemi vurgulanmıştır.

Karacan (2020) çalışmasında salgının finansal tablolara olası etkilerini tartışmıştır. Bilindiği gibi halka açık şirketler, sigorta şirketleri, finansal kuruluşlar gibi kamuoyunun yakından takip ettiği işletmeler 2019 yılına ait finansal tablolarını pandemi ilan edilmeden önce yayınlamışlardır. Pandeminin etkisinin finansal raporlarda "düzeltme gerektirmeyen olay" olarak değerlendirilmesi ve "dipnotlarda açıklama yapılması gereken bir olay" olarak raporlanması gerektiğini vurgulamıştır.

Sanova (2021), Covid-19'un küresel etkisini işletmenin sürekliliği kavramı ile açıklamıştır. Bulgaristan Menkul Kıymetler Borsa'sında işlem gören finans sektörü dışındaki şirketlerin 2020 yılının ilk çeyreğine ait ara dönem finansal raporlarını incelediği çalışmasında; işletmenin sürekliliği ilkesinin işleyişini ele almıştır. Şirketlerin gelirleri, karlılığı ve net nakit kullanılabilirliğine ilişkin önceki yıla ait yıllık finansal tablolarda yer alan açıklamaların, cari dönemin ilk çeyreğine ait ara dönem finansal tablolarda yer alan bilgilerle tutarlı olduğunu tespit etmiştir.

Ernst \& Young (2020), KPMG (2020), PWC (2020) ve GrantThornton (2020) denetim şirketleri yayınlarında Covid-19'un etkileri değerlendirilirken göz önüne alınması gereken temel muhasebe ve finansal hususlardan bahsetmişlerdir. Bunlar; işletmenin sürekliliugi, muhasebe tahminleri, gerçeğe uygun değerin tespit edilmesi, hasılatın kaydı, kiralama standardı, finansal raporlama üzerindeki iç kontroller, çalışanlara sağlanan faydalar, devlet teşvikleri ve faaliyet raporlarındaki açıklamalardır. Ayrıca Covid-19 salgınının finansal etkilerini ele alan 2020 'de sona eren ara dönem veya y1llık raporlama dönemi için IFRS mali tablolarının düzenlenmesinde dikkate alınacak mevcut muhasebe standartları üzerinde durmuşlardır. Bunun yanı sıra yayınlarında ara dönem ve yıllık mali tablolar için açıklanması gereken hususlara yer verilmiş ve ara dönem raporlama tarihinden sonra meydana gelen olayların açıklanmasına da değinilmiştir.

Denetim şirketlerinin Covid-19'un finansal raporlamaya etkilerine ilişkin çalışmalarına benzer yayınlar TÜRMOB (2020), İstanbul SMMM Odası (2020) gibi meslek kuruluşları tarafından da yapılmıştır. Covid-19'un hesaplar üzerine etkisi ile standartların uygulanmasına ilişkin tespitlerin yakın olmasının yanı sıra bu ortamda düzenlenen finansal raporların bağımız denetiminde dikkate alınacak hususlar da açıklanmıştır. 


\section{ARAŞTIRMA}

\subsection{Araştırmanın Amacı, Kapsamı ve Yöntemi}

Araştırmanın amacı, Covid-19’un ara dönem finansal raporlama üzerindeki etkilerini ortaya koymaktır. Bu amaçla araştırmamıza BİST 100 endeksindeki havacılık sektörü olumsuz etkilenen sektör (Deloitte, 2020), ilaç sektörü ise olumlu etkilenen (KPMG, 2020) olarak dahil edilmiştir. BISST 100'de havacılık ve ilaç sektörlerinde işlem gören şirketlerin 30.06.2020 ve 30.09.2020 tarihlerindeki ara dönem finansal tabloları ile bir önceki yılın aynı ara dönemine ait finansal tabloları karşılaştırılarak sektör bazında değerlendirilmesi yapılmıştır. Ulaşılan sonuçlar BİST 100'deki havacılık ve ilaç sektörü işletmelerine ait olup, orta ve küçük boy işletmelerinin genel durumunu yansıtmadığını vurgulamak gerekir.

Dünya Sağlık Örgütü tarafından 11.03.2020 tarihinde Covid-19 ile ilgili pandemi ilan edilmiş ve Türkiye'de bu tarihten sonra sosyal ve ekonomik hayatla ilgili kısıtlamalar uygulanmış, Haziran ayı içerisinde kademeli olarak normalleşmeye geçilmiştir. Dolayısıyla pandeminin ilk etkileri Haziran 2020 ara dönem finansal tablolarına ve kısitlamaların kademeli olarak gevşetilmesinin etkisi ise Eylül 2020 ara dönem finansal tablolarına yansımıştır. $\mathrm{Bu}$ nedenle araştırmamıza 30.06.2019, 30.06.2020, 30.09.2019 ve 30.09.2020 tarihlerindeki finansal raporlar dahil edilmiştir. İlgili raporlar Kamuyu Aydınlatma Platformu'nun (KAP) internet sitesi olan www.kap.gov.tr'den alınmıştır.

BİST 100 endeksindeki havacılık sektöründe THY, TAV ve PEGASUS, ilaç sektöründe ise DEVA, ECZACIBAŞI ve SELÇUK işletmeleri yer almaktadır. Bu işletmelerin belirlenen tarihlerdeki ara dönem finansal tabloları ile ekleri incelenmiş ve pandemiden etkileneceği öngörülen finansal tablo kalemlerinin toplamı alınarak sektörel bazda ara dönemler itibariyle karşılaştırmalı olarak değerlendirilmesi yapılmıştır. Yukarıda açıklanan olası etkiler ile gerçekte tespit edilen etkiler ortaya konulmaya çalış1lmıştır. Dikey ve oran analizi çalışmanın kapsamına dahil edilmemiş, daha ziyade dipnot içerik analizi yapılarak finansal bulgular değerlendirilmiştir.

\subsection{Araştırma Bulguları}

Araştırma kapsamında bulunan şirketlerin, belirlenen tarihlerdeki ara dönem finansal raporlarında tespit edilen kalemleri ayrı ayrı toplanmış ve sektör tutarına ulaşılmıştır. Havacılık ve ilaç sektörlerinde salgından dolayı eklenen yeni bilgilerin değerlendirilmesi ve finansal raporlardaki farklılıkların tespit edilebilmesi için ara dönemlerdeki finansal durum tablosu, kar veya zarar ve diğer kapsamlı gelir tablosu kalemleri ayrı ayrı incelenmiştir. Nakit ve nakit benzeri varlık değişimlerinin yorumlanmasında nakit akış tablolarındaki bilgiler de dikkate alınmış, tekrardan kaçınmak adına nakit akış tablosuna ayrıca yer verilmemiştir.

\subsubsection{Finansal Durum Tablosu Kalemlerinin ve Dipnotlarının İncelenmesi}

Araştırma kısıtları çerçevesinde içerik analizi yapılmış ve tespit edilen finansal durum tablosu kalemleri hem havacılık sektörü hem de ilaç sektörü açısından ayrı ayrı değerlendirilmiştir. Covid-19 salgını nedeniyle ilaç sektöründeki işletmelerin 30.06.2019 ve 30.06.2020 ile 30.09.2019 ve 30.09.2020 tarihlerinde etkilenen finansal durum tablosu kalemleri ve yüzdesel değişimleri Tablo 1'de yer almaktadır. 
Tablo 1. İlaç Sektöründeki İşletmelerin Finansal Durum Tablosu Kalemlerinin Karşılaştırılması

\begin{tabular}{|c|c|c|c|c|c|c|}
\hline \multicolumn{7}{|c|}{ İLAÇ SEKTÖRÜNDEKİ İŞLETMELERİN FİNANSAL DURUM TABLOSU KALEMLERİ (BİN TL) } \\
\hline FINANSAL DURUM TABLOSU KALEMLERİ & 30.06.2019 & 30.06.2020 & Yüzde Değişim & 30.09.2019 & 30.09 .2020 & Yüzde Değişim \\
\hline Nakit ve Nakit Benzerleri & 1.308 .647 & 2.421 .414 & $85,03 \%$ & 1.560 .886 & 2.499 .268 & $60,12 \%$ \\
\hline Kısa Vadeli Finansal Yatırımlar & 1.233 & 2.109 & $71,05 \%$ & 1.204 & 18.213 & $1412,71 \%$ \\
\hline Kısa Vadeli Ticari Alacaklar & 4.876 .621 & 5.341 .763 & $9,54 \%$ & 5.108 .579 & 5.841 .591 & $14,35 \%$ \\
\hline Türev Finansal Varlıklar & 0 & 3.356 & $335 \%$ & 0 & 12.280 & $12280 \%$ \\
\hline Stoklar & 2.069 .151 & 2.496 .601 & $20,66 \%$ & 2.130 .493 & 2.490 .896 & $16,92 \%$ \\
\hline Stok Değer Düşüklüğü Karşılığ1 & 14.582 & 43.022 & $195,03 \%$ & 18.199 & 59.523 & $227,07 \%$ \\
\hline Kısa Vadeli Peşin Ödenmiş Giderler & 41.970 & 66.719 & $58,97 \%$ & 34.488 & 43.690 & $26,68 \%$ \\
\hline Cari Dönem Vergisiyle İlgili Varlıklar & 204 & 3.033 & $1386,76 \%$ & 1.075 & 4.730 & $340,00 \%$ \\
\hline Maddi Duran Varlıklar & 1.076 .116 & 1.269 .509 & $17,97 \%$ & 1.108 .875 & 1.317 .174 & $18,78 \%$ \\
\hline Kullanım Hakkı Varlıkları & 75.820 & 80.313 & $5,93 \%$ & 69.200 & 76.227 & $10,15 \%$ \\
\hline Maddi Olmayan Duran Varlıklar & 325.985 & 345.577 & $6,01 \%$ & 335.648 & 332.328 & $-0,99 \%$ \\
\hline Uzun Vadeli Peşin Ödenmiş Giderler & 35.283 & 87.151 & $147,01 \%$ & 38.244 & 89.016 & $132,76 \%$ \\
\hline Kisa Vadeli Borçlanmalar & 470.500 & 1.445 .944 & $207,32 \%$ & 584.080 & 546.164 & $-6,49 \%$ \\
\hline Kısa Vadeli Kiralama İşlemlerinden Borçlar & 18.466 & 32.185 & $74,29 \%$ & 17.591 & 34.472 & $95,96 \%$ \\
\hline Çalışanlara sağlanan faydalar kapsamında borçlar & 48.124 & 42.936 & $-10,78 \%$ & 40.214 & 45.207 & $12,42 \%$ \\
\hline Kıdem Tazminatı Karşılığı & 68.367 & 90.462 & $32,32 \%$ & 70.912 & 93.355 & $31,65 \%$ \\
\hline Türev Finansal Yükümlülükler & 23.936 & 5.418 & $-77,36 \%$ & 35.824 & 0 & $-100,00 \%$ \\
\hline Kısa Vadeli Devlet Teşvik ve Yardımları & 1.612 & 1.668 & $3,47 \%$ & 1.495 & 1.730 & $15,72 \%$ \\
\hline Uzun Vadeli Borçlanmalar & 279.106 & 500.633 & $79,37 \%$ & 251.026 & 418.967 & $66,90 \%$ \\
\hline Uzun Vadeli Kiralama İşlemlerinden Borçlar & 49.288 & 58.196 & $18,07 \%$ & 44.470 & 54.155 & $21,78 \%$ \\
\hline Uzun Vadeli Devlet Teşvik ve Yardımları & 33.124 & 39.644 & $19,68 \%$ & 36.607 & 43.103 & $17,75 \%$ \\
\hline
\end{tabular}


İlaç sektöründe yer alan şirketlerin 30.06.2020'de ve 30.09.2020'de nakit ve nakit benzerleri kalemi \%60,12 ile \%85,03 oranında artmıştır. Her iki tarihte de oluşan fark vadeli mevduat hesaplarındaki artıştan kaynaklanmıştır. Salgının neden olduğu belirsizlik nedeniyle sektördeki şirketler nakit bulundurma ihtiyacı hissetmişler ve finansal yatırımlarını kısa vadeli yapmışlardır. Ancak bu durum sektörde yer alan iki işletme tarafından Covid-19'un etkisi olarak finansal tablo dipnotlarında belirtilmemiştir. Sektördeki bir şirket likidite pozisyonunu güçlendirmek adına nakit yönetim stratejisini gözden geçirdiğini pandeminin etkisi olarak dipnotlarında açıklamıştır. Öte yandan nakit akış tablosunu incelediğimizde ilaç sektöründeki işletmelerin her iki ara dönemde işletme faaliyetlerinden ve yatırım faaliyetlerinden nakit çıkışları, finansman faaliyetleriyle ilgili her iki dönemde de nakit girişi gerçekleşmiş olduğu görülmektedir. Yatırım faaliyetlerinde oluşan nakit çıkışı sektördeki işletmelerin yeni yatırımlara ve gelecek yılda büyüme potansiyeline işaret etmektedir.

Sektördeki şirketlerin kısa vadeli ticari alacakları her iki ara dönemde yaklaşık ortalama \%11,54 oranında artış göstermiştir. Finansal durum tablolarında uzun vadeli ticari alacakları bulunmamaktadır. Salgın nedeniyle şirketler şüpheli ticari alacak riskini asgariye indirgemeyi amaçlamaktadır. Alacak tahsilatındaki gecikme ticari nedenlerden ve eczanelere tanınan opsiyonlardaki artıştan kaynaklandığından vadesi geçmiş alacak olarak değerlendirilmemiş, bu durum dipnotlarda açıklanmıştır.

Sektörde yer alan 3 işletmeden sadece biri satın alma hakkı olarak türev araçlarından yararlanmıştır. $\mathrm{Bu}$ şirket yabancı para cinsinden yapılan alımlardan kaynaklanabilecek kur riskinden korunma amaçlı türev ürünlerini kullanmıştır. Türev araç işlemlerinden kaynaklanan borçların ise her iki ara dönemde de \%70'den fazla azaldığ 1 görülmektedir. Bu konuyla ilgili herhangi bir dipnot açıklaması bulunmamaktadır.

Covid-19 nedeniyle oluşan belirsizlik, stoklarda net gerçekleşebilir değer tahmininin güvenilir olarak yapılamamasına neden olmuştur. $\mathrm{Bu}$ durum ilaç sektöründe bulunan şirketlerin Stoklar kaleminde artış meydana getirmiştir. Bununla birlikte, Ar-Ge ve kalite değerlendirmeleri sonucunda tekrar kullanılamayacağı düşünülen ürünler için ayrılan değer düşüklüğü karşılığının da arttığı görülmüştür.

Kısa vadeli peşin ödenmiş giderler ve uzun vadeli peşin ödenmiş giderler kalemleri her iki dönemde artış göstermiştir. Kısa vadeli artışın stoklar alımı için verilen sipariş avanslarından, uzun vadeli artışın ise sabit kıymet alımı için verilen avanslardan kaynaklandığı görülmektedir.

Peşin ödenen ve indirim konusu yapılabilecek gelir üzerinden ödenecek çeşitli vergi ve fonların gösterildiği cari dönem vergisiyle ilgili varlıklar kaleminin 30.06.2020'de $\% 1386,76$ oranında ve 30.09.2020'de \%340 oranında yüksek bir artış gösterdiği görülmektedir. Bu kalemle ilgili olarak hem 30.06.2020'de hem de 30.09.2020'de sadece bir şirket dipnot açıklamasında bulunmuş ve peşin ödenen banka stopajı ile ilgili bilgisini vermiştir.

Maddi duran varlıklar kalemi her iki ara dönemde de yaklaşık \%18 oranında artmıştır. 30.06.2020'de sektördeki şirketlerde tesis, makine ve cihaz alımlarının arttığı ve yapılmakta olan yatırımların ise azaldığ 1 görülmektedir. 30.09.2020'de ise hem tesis, makine ve cihaz alımları hem de yapılmakta olan yatırımlar artmıştır. Maddi olmayan duran varlıklar kalemi 
ise 30.06.2020'de artmış, 30.09.2020'de ise azalmıştır. 30.06.2020'deki artışın nedeni çoğunlukla işletmeler içerisinde geliştirilen ve lisansları alınmış ürün alımlarından, 30.09.2020'deki azalış ise amortisman giderlerinden kaynaklanmıştır.

TFRS 16 Kiralamalar Standardı'na göre muhasebeleştirilen kullanım hakkı varlıkları kalemi her iki ara dönemde de yaklaşık ortalama $\% 8$ artmıştır. $\mathrm{Bu}$ artışın nedeni ilaç sektöründeki iki şirketin faaliyet kiralaması yapmasıdır. Salgından dolayı ilaç sektöründeki satışların artması beklentisi, üretimin artmasına neden olacağından şirketler makine kiralamışlardır. Her iki dönemde de kısa vadeli kiralama işlemlerinden borçlar kalemi artmıştır. Uzun vadeli kiralama işlemlerinden borçlar ise daha az artış göstermiştir. Pandeminin neden olduğu belirsizlik nedeniyle şirketlerin kiralama yükümlülükleri kısa vadeli olmuştur.

İlaç sektöründeki şirketlerin 30.06.2020'de genel borçlanma politikası ağırlıklı olarak sabit faizli ve kısa vadelidir. Bu ara dönemde kısa vadeli borçlanmalar kalemi, uzun vadeli borçlanmalar kalemine göre \%100'den fazla artmıştır. 2 Mayıs 2020 tarihli Resmi Gazete'de yayımlanan tebliğ değişikliği ile solunum cihazları ve sarf malzemelerin ihracatında Türkiye İlaç ve Tıbbi Cihazlar Kurumu'ndan ve Ticaret Bakanlığı'ndan izin alınması uygulamasına da son verilmiştir. Bu durum şirketlerin stok alımlarını arttırmıştır. Şirketlerin nakit bulundurma politikası nedeniyle stok alımları kısa vadeli banka kredileri ile sağlanmıştır. Ancak bu durum 30.06.2020'de Covid-19'un etkisi olarak finansal tablo dipnotlarına yansımamıştır. 30.09.2020'de ise şirketler tahvil çıkararak uzun vadeli borçlanma politikası benimsemişlerdir.

Çalışanlara sağlanan faydalar kapsamında borçlar kalemi 30.06.2020'de \%10,78 oranında azalmış, 30.09.2020'de ise \%12,42 oranında artmıştır. Salgın nedeni ile ödenecek sosyal güvenlik kesintilerinin ertelenmesi ile ilgili tebliğ nedeniyle azalış olmuştur. Ancak dipnotlarda bu durum açıklanmamıştır. Artışın nedeni ise personele ödenecek ücretlerdeki artışlardan kaynaklanmıştır. Çalışanlara ilişkin ara dönem emeklilik maliyetleri yani Kıdem Tazminatı Karşılıkları ise her iki ara dönemde yaklaşık ortalama \%31 oranında artmıştır. Mevzuata göre kıdem tazminatı yükümlülüklerinin tamamı için karşılık ayrılmıştır.

Kısa vadeli devlet teşvik ve destekleri ile uzun dönem devlet teşvik ve destekleri kalemleri hem 30.06.2020 hem de 30.09.2020 tarihlerindeki ara dönem finansal tablolarda artış göstermiştir. Sektörde yer alan sadece bir şirket geliştirme giderleri nedeniyle devlet teşviği almıştır. Sektördeki diğer bir şirket ise gelir vergisi stopajı, sigorta primi işveren paylarında teşvik ile enerji desteğinden yararlanmıştır.

Pandeminin etkisi olarak ilaç sektöründe yer alan üç işletmeden ikisi hem 30.06.2020 hem de 30.09.2020 tarihlerindeki ara dönem finansal tablolarında "Cari Döneme İlişkin Önemli Değişiklikler” başlığı altındaki dipnotlarında yatırım harcamaları, operasyonel giderler ve stoklardaki artışın olumsuz etkilerini en düşük seviyede tutmak için önlemler alındığını ve finansal tabloların hazırlanmasında kullanılan tahmin ve varsayımların gözden geçirildiğini belirtmişlerdir. Stoklar, maddi ve maddi olmayan duran varlıkların değerlerinde meydana gelebilecek muhtemel değer düşüklüklerinin test edildiğini ve herhangi bir değer düşüklüğü tespit edilmediğini vurgulamışlardır. Ayrıca kısa çalışma ödeneğinden yararlanıldı̆̆ bilgisi yer almaktadır. 
Covid-19 salgını nedeniyle havacılık sektöründeki işletmelerin 30.06.2019 ve 30.06.2020 ile 30.09.2019 ve 30.09.2020 tarihlerinde etkilenen finansal durum tablosu kalemleri ve yüzdesel değişimleri Tablo 2'de yer almaktadır.

Havacılık sektöründe yer alan şirketlerin nakit ve nakit benzerleri kalemi her iki dönemde de artış göstermiştir. Bu artış kısıtlamaların etkisinin yansıtıldı̆̆ 30.06 .2020 'de daha fazla olmuştur. Sektördeki işletmeler pandeminin yarattığı olumsuz etkiyi azaltmak ve gelecekteki belirsizlik nedeniyle nakit pozisyonlarını arttırma yoluna gitmişlerdir. Şirketlerin işletme faaliyetlerinden nakit akış çıkışı, yatırım faaliyetlerinden ve finansman faaliyetlerinden nakit akışlarının ise pozitif yani giriş şeklinde bir değişim gösterdiği tespit edilmiştir. Nakit pozisyonunu arttırma konusunda alınan önlemler sektörde yer alan iki şirket tarafindan 30.06.2020 ve 30.09.2020 tarihli ara dönem finansal tablo dipnotlarında aşağıdaki şekilde belirtilmiştir.

- $\quad$ Personel maliyetlerini optimize etmek amacıyla kısa dönem çalışma ödeneğinden faydalanılmıştır.

- Personelin uzaktan çalışma sistemine geçirilmesiyle maliyetlerde tasarruf sağlanmıştır.

- Tedarikçiler ile ödemelerin ertelenmesi için işbirliği görüşmeleri yürütülmüştür.

- Uçak bakım takvimi optimize edilerek mevcut kullanım planlarına göre güncellenmiştir.

- Genel gider harcama bütçeleri indirilmiş, kritik olmayan proje ve yatırımlar ertelenmiştir.

- Nakit akışı sağlamak amacıyla kısa vadeli banka kredisi kullanma yolu tercih edilmiştir.

- $\quad$ Ticari kredilerine ilişkin anapara ve faiz ödemelerinin bir kısmını en az 3 ay süre ile ertelemiştir.

- $\quad$ Bazı uzun dönem sözleşmelere (akaryakıt ve kiralama gibi) ilişkin ödemeler 3 ile 6 ay arasında ertelenmiştir.

Havacılık sektöründeki işletmelerin hem 30.06.2020'de hem de 30.09.2020'de Kısa Vadeli Finansal Yatırımları azalırken, Uzun Vadeli Finansal Yatırımları ise artış göstermiştir. $\mathrm{Bu}$ artışların nedeni uzun vadeli yabancı para ile yapılan yatırımlardan kaynaklanmaktadır.

Kısa vadeli ticari alacaklar kalemi her iki dönemde de azalış göstermiştir. Ticari alacaklara ilişkin ortalama tahsilat süresi 2019 yılının ikinci ve üçüncü çeyreğinde ortalama 19 gün iken 2020 yılının aynı dönemlerinde ortalama 50 gün olarak artmıştır. Sektörde yer alan bir işletme IFRS 9'a istinaden ticari alacaklara ilişkin beklenen kredi karşıllı̆ hesaplamasında yer alan tarihi zarar oranlarının salgına dair geleceğe yönelik bilgileri de yansıtacak şekilde güncellendiğini dipnotlarında belirtmiştir. Uzun vadeli ticari alacakları ise her iki tarihteki finansal durum tablosunda bulunmamaktadır.

İşletmelerin kısa vadeli ve uzun vadeli diğer alacaklar kalemleri hem 30.06.2020’de hem de 30.09.2020'de artış göstermiştir. Bu artışların nedeni ilişkili olmayan taraflardan diğer alacaklardan kaynaklanmaktadır. Pilotlara ilişkin eğitim alacaklarına dair karşılık hesaplamalarında kullanılan yönetim tahminlerinin salgın nedeniyle değişen güncel ortamı yansıtacak şekilde yeniden değerlendirildiği bir şirketin dipnotunda yer almaktadır. 
Tablo 2. Havacılık Sektöründeki İşletmelerin Finansal Durum Tablosu Kalemlerinin Karşılaştırılması

\begin{tabular}{|c|c|c|c|c|c|c|}
\hline \multicolumn{7}{|c|}{ HAVACILIK SEKTÖRÜNDEKİ İȘLETMELERIN FINANSAL DURUM TABLOSU KALEMLERİ (BIIN TL) } \\
\hline FINANSAL DURUM TABLOSU KALEMLERİ & 30.06.2019 & 30.06.2020 & Yüzde Değişim & 30.09.2019 & 30.09.2020 & Yüzde Değişim \\
\hline Nakit ve Nakit Benzerleri & 13.934 .537 & 21.392 .626 & $53,52 \%$ & 17.531 .237 & 20.580 .677 & $17,39 \%$ \\
\hline Kısa Vadeli Finansal Yatırımlar & 3.269 .452 & 669.984 & $-79,51 \%$ & 1.239 .110 & 882.493 & $-28,78 \%$ \\
\hline Kısa Vadeli Ticari Alacaklar & 5.817 .006 & 2.855 .375 & $-50,91 \%$ & 5.454 .944 & 4.483 .850 & $-17,80 \%$ \\
\hline Kısa Vadeli Diğer Alacaklar & 10.232 .655 & 12.328 .327 & $20,48 \%$ & 6.996 .592 & 13.437 .168 & $92,05 \%$ \\
\hline Türev Finansal Varlıklar & 304.210 & 345.675 & $13,63 \%$ & 493.655 & 161.547 & $-67,28 \%$ \\
\hline Uzun Vadeli Finansal Yatırımlar & 481.000 & 794.314 & $65,14 \%$ & 646.508 & 893.926 & $38,27 \%$ \\
\hline Uzun Vadeli Diğer Alacaklar & 4.995 .550 & 7.903 .802 & $58,22 \%$ & 7.363 .086 & 8.430 .648 & $14,50 \%$ \\
\hline Maddi Duran Varlıklar & 94.334 .740 & 127.867 .095 & $35,55 \%$ & 98.427 .255 & 148.173 .453 & $50,54 \%$ \\
\hline Kullanım Hakkı Varlıkları & 11.560 .188 & 15.982 .233 & $38,25 \%$ & 11.154 .241 & 18.501 .704 & $65,87 \%$ \\
\hline Maddi Olmayan Duran Varlıklar & 11.629 .572 & 14.071 .437 & $21,00 \%$ & 10.863 .887 & 16.472 .283 & $51,62 \%$ \\
\hline Kısa Vadeli Borçlanmalar & 10.309 .762 & 17.049 .994 & $65,38 \%$ & 9.756 .692 & 18.755 .638 & $92,23 \%$ \\
\hline Uzun vadeli borçlanmaların Kısa Vadeli Kısımları & 10.306 .895 & 16.705 .348 & $62,08 \%$ & 10.494 .503 & 20.278 .774 & $93,23 \%$ \\
\hline Kısa Vadeli Kiralama İşlemlerinden Borçlar & 2.001 .869 & 4.023 .202 & $100,97 \%$ & 3.190 .396 & 4.899 .191 & $53,56 \%$ \\
\hline Çalışanlara sağlanan faydalar kapsamında borçlar & 1.171 .487 & 1.346 .675 & $14,95 \%$ & 1.340 .360 & 1.025 .015 & $-23,53 \%$ \\
\hline Türev Finansal Yükümlülükler & 1.010 .160 & 2.320 .835 & $129,75 \%$ & 1.240 .482 & 1.800 .679 & $45,16 \%$ \\
\hline Uzun Vadeli Borçlanmalar & 59.971 .010 & 79.780 .243 & $33,03 \%$ & 60.851 .924 & 96.804 .767 & $59,08 \%$ \\
\hline Uzun Vadeli Kiralama İşlemlerinden Borçlar & 8.815 .986 & 21.431 .553 & $143,10 \%$ & 16.529 .255 & 26.505 .366 & $60,35 \%$ \\
\hline
\end{tabular}


Sektörde yer alan işletmeler Covid 19'un neden olduğu belirsizlik nedeniyle, faiz oranı ve döviz işlemlerini kapsayan riskten korunma araçlarına başvurmuşlardır. Akaryakıt fiyat riskinin, sermaye maliyetlerinin ve gelirdeki dalgalanmaların azalmasını sağlamak amacıyla başvurulan türev finansal varlıklar kalemi 30.06.2020'de \%13,63 oranında artarken 30.09.2020'de \%67,28 oranında azalmıştır. Bu değişimin nedeni Haziran ayından sonra kısıtlamaların kademeli olarak gevşetilmesinin etkisi olarak gösterilebilir. Türev Finansal Yükümlülükleri kalemi ise hem 30.06.2020'de hem de 30.09.2020'de artış göstermiştir.

Şirketlerin maddi duran varlıkları her iki ara dönemde de yaklaşık ortalama \%43 oranında artış göstermiştir. Bu değişim makine ve teçhizat, komponent ve tamir edilebilir yedek parça ile kargo ekipman alımlarından kaynaklanmıştır. Maddi olmayan duran varlıklar kalemi de 2020 yılı ikinci ve üçüncü çeyreğinde artmıştır. Bu artışların nedeninin imtiyazlı sözleşmelerden doğan haklardan kaynaklandığı görülmüştür.

Havacılık sektöründe uçak alım maliyetlerinin yüksek olması nedeniyle kullanım hakkı varlıkları önemli bir kalemdir. Her iki dönemde de kullanım hakkı varlıkları pozitif bir değişim göstermiştir. Kısıtlamaların gevşetilmesi ile birlikte kullanım hakkı varlıkları kalemi 30.09.2020'de daha fazla artmıştır. Covid 19 nedeniyle kargo taşımacılık faaliyetlerine ağırlık veren şirketler filo kiralama yolunu tercih etmişlerdir. Sektörde yer alan bir işletme hem 30.06.2020 hem de 30.09.2020 tarihlerindeki ara dönem finansal tablolarında pandemi nedeniyle filo ve kullanım hakkı varlıklarını yeniden gözden geçirdiğini ve değer düşüklüğü testleri uyguladığını ve değer düşüklüğü tespit edemediğini belirtmiştir.

Şirketlerin genel borçlanma politikası kısa vadelidir. Kısa vadeli ticari borçları sabit faizli banka kredilerinden ve değişken faizli kiralama yükümlülüklerinden oluşmaktadır. Ticari kredilerine ilişkin anapara ve faiz ödemelerinin ertelendiği dipnotlarda belirtilmiştir. Sektörde yer alan bir şirket hem 30.06.2020 hem de 30.09.2020 tarihlerinde kredi borçlarının yapılandırma süreciyle ilgili anlaşma ve ilave finansal dokümanların kredi verenlerle imzalandığını ve Covid-19 etkisi nedeniyle refinansmanda bazı küçük düzenlemeler yapıldığını ama bu durumun şirketi ve sermayedarlarını etkileyecek düzeyde olmadığını vurgulamıştır.

Havacılık sektöründeki işletmelerin 30.06.2020 tarihinde bir önceki yıla göre hem kısa vadeli kiralama işlemlerinden borçları hem de uzun vadeli kiralama işlemlerinden borçları ise \%100'ün üzerinde ciddi bir artış göstermiştir. 30.09.2020 tarihinde ise kısa vadeli kiralama işlemlerinden borçları ve uzun vadeli kiralama işlemlerinden borçları 30.06.2020'ye göre daha az artmıştır. Her iki dönemde de oluşan artışlar hem operasyonel kiralama borçlarından hem de finansal kiralama borçlarından kaynaklanmaktadır.

Şirketler Covid 19 salgını nedeniyle muhasebe politika ve tahminlerini, çalışanlara sağlanan faydalar kapsamında ayrılan karşılıkların hesaplanmasında kullanılan iskonto oranlarını tekrar değerlendirmişlerdir. Sektörde yer alan bir şirket hem 30.06.2020 hem de 30.09.2020 tarihlerindeki ara dönem finansal tablo dipnotlarındaki iskonto oranlarının 31.12.2019 tarihinden beri arttığını ve bu artışın iskonto edilmiş nakit akımlarına dayanarak tahmin edilen varlıkların geri kazanılabilir tutarı üzerinde olumsuz bir etkisi olduğunu belirtmişlerdir. 
BİST 100'de havacıllk sektöründe yer alan üç işletmeden sadece biri hem 30.06.2020 hem de 30.09.2020 tarihlerindeki finansal tablo dipnotlarında Covid 19 nedeni ile sağlanan devlet teşviklerinden bahsetmiştir. Bunlara örnek olarak; yurtiçi havayolu taşımacılığında talebi düşük bilet fiyatları için üç ay süreyle KDV oranının \%18'den \%1'e indirilmesi (30 Haziran 2020'ye kadar) ile Nisan, Mayıs ve Haziran aylarına ait tahakkuk eden KDV ve SGK prim ödemelerinin 6 ay süre ile 2021 yılına ertelenmesi verilebilir.

\subsubsection{Kar veya Zarar ve Diğer Kapsamlı Gelir Tablosu Kalemlerinin ve Dipnotların İncelenmesi}

Araştırmamız kapsamında kar veya zarar ve diğer kapsamlı gelir tablosu kalemlerinde değişim gösteren kalemler hem ilaç sektörü hem de havacılık sektörü açısından ayrı ayrı değerlendirilmiştir. Pandemi nedeniyle ilaç sektöründeki işletmelerin 30.06.2019 ve 30.06.2020 ile 30.09.2019 ve 30.09.2020 tarihlerinde etkilenen gelir tablosu ve kapsamlı gelir tablosu kalemleri ve yüzdesel değişimleri Tablo 3'de yer almaktadır.

İlaç sektöründeki şirketlerin her iki ara dönemde hasılatın yaklaşık ortalama \%20 oranında arttığı görülmektedir. $\mathrm{Bu}$ artışın nedeni şirketlerin faaliyet raporlarında pandemi nedeniyle beslenme ve metabolizma segmentindeki ilaç ve gıda takviyeleri satışlarının artması olarak açıklanmıştır.

İlaç sektöründe brüt satış karının hasılata göre daha az arttığı tespit edilmiştir. Bu durum satışların maliyeti kalemlerindeki artıştan kaynaklanmaktadır. Sektördeki bir şirket satışların maliyetini oluşturan kalemlerdeki artışın üretim giderlerinden kaynaklandığını dipnotlarında ayrıntılı açıklamış, diğer şirketler ise herhangi bir açıklamaya yer vermemişlerdir.

Personel giderleri ise her iki ara dönemde yaklaşık ortalama \%14 oranında artış göstermiştir. Personel giderlerini oluşturan kalemlere baktığımızda pazarlama, satış ve dağıtım giderleri azalmış, Ar-Ge ve genel yönetim giderleri ise artmıştır. Pandemi sebebiyle sağlık kurum ve kuruluşlarında tanıtım faaliyetlerine ara verilmesi pazarlama, satış ve dağıtım bölümündeki personel giderlerinin azalmasına neden olmuştur. Ancak bu durum işletmelerin faaliyet raporlarında yer almasına rağmen dipnotlarda belirtilmemiştir.

Finansman giderleri kalemi 30.06.2020'ye göre 30.09.2020'de daha fazla artış göstermiştir. Eylül dönemindeki bu artış sektörde yer alan üç şirket için de banka kredileri faiz giderleri ve kiralama işlemleri kur farkı giderlerindeki artıştan kaynaklanmıştır.

İlaç sektöründe faaliyet gösteren şirketlerin 2020 yılı ikinci ve üçüncü çeyrekte faaliyetlerinden elde edilen vergi öncesi karı yaklaşık \%40 oranında artış göstermiştir. Diğer taraftan dönem vergi giderinde dikkat çekici bir artış gerçekleşmemiştir. Bunun nedeni teşvik kapsamındaki harcamalarda muhtelif vergi avantajlarının bulunmasıdır.

Muhasebe karı ile mali kar arasındaki geçici farkların raporlandığı ertelenmiş vergi geliri/gideri kalemi 30.06.2020'de \%105,44 oranında azalmıştır. Azalışın nedeninin cari dönem vergi giderlerindeki artıştan kaynaklandığı dipnotlarda belirtilmiştir. Sektördeki işletmelerin 30.09.2020'deki finansal tablolarındaki vergi geliri/gideri kalemi ise önemli ölçüde değişiklik göstermemiştir. 
İlaç sektöründe yer alan üç işletmede de diğer kapsamlı gelir tablosunda gösterilen yabancı para çevrim farkları ile ilgili dipnot açıklaması her iki dönemde de ara dönem finansal tablolarda yer almamaktadır. Özellikle 30.09.2020'deki yabancı para çevrim farklarındaki \%60,25 oranındaki azalış ile toplam kapsamlı gelirdeki \%43 oranındaki artış dikkat çekicidir. Diğer kapsamlı gelir kalemi ise 30.06.2020'de \%1570,64 oranında ve 30.09.2020'de ise \%529,44 oranında azalmıştır. Bu kalemle ilgili dipnot açıklaması bulunmamaktadır.

Salgın nedeniyle havacılık sektöründeki işletmelerin 30.06.2019 ve 30.06.2020 ile 30.09.2019 ve 30.09.2020 tarihlerinde etkilenen kar veya zarar ve diğer kapsamlı gelir tablosu kalemleri ve yüzdesel değişimleri Tablo 4'de yer almaktadır.

Havacılık sektöründeki işletmelerin hasılatı her iki dönemde de yaklaşık ortalama \%43 oranında azalmıştır. Her iki dönemde de bir şirket için yolcu gelirlerinde azalma olmasına rağmen kargo gelirlerinde \%100'den fazla artış olmuştur. Satışların maliyeti kalemi aynı oranda azalmadığı için brüt satış zararı kısıtlamaların olduğu 30.06.2020'de \%113,16 oranında azalmıştır. Kısıtlamaların kaldırılması ile 30.09.2020'de brüt satış zararındaki artış azalmıştır.

Hükümetin sağladığı kısa dönem çalışma ödeneğinden faydalanılması ve uzaktan çalışma sistemine geçilmesiyle sektörde personel giderlerinde tasarruf sağlanmıştır. Ayrıca çalışılan gün sayısına bağlı olarak personel giderlerinin bir kısmı devlet teşvikinden karşılanmıştır. Bu durum pandeminin etkisi olarak şirketlerin her iki dönem ara dönem finansal tablo dipnotlarında belirtilmiştir.

Faaliyet giderleri her iki ara dönemde yaklaşık ortalama \%34 oranında azalmıştır. Bu azalış pazarlama ve satış giderlerinden kaynaklanmıştır. Ayrıca salgın nedeniyle yolcu hizmet ve ikram giderleri ile akaryakıt giderlerinin 2020 yılı ikinci ve üçüncü çeyreklerinde bir önceki yıla göre \%40'dan fazla azaldığı görülmektedir.

Finansman giderleri her iki ara dönemde de artış göstermiştir. Bu artışın iki şirket için komisyon giderlerinden ve bir şirket için yabancı para cinsinden olan işlemlerin çevriminden doğan çevrim karının/zararının finansman giderleri olarak muhasebeleştirilmesinden kaynaklandığı görülmektedir.

Covid 19'un etkisi olarak beklendiği üzere faaliyetlerinden elde edilen vergi öncesi karındaki azalış 30.06.2020'de \%356,47 oranında ve 30.09.2020'de ise \%269,72 oranında gerçekleşmiştir. Yolcu taşımacılığının durdurulduğu dönemde zararın daha fazla olduğu, kısıtlamalarının kaldırılması ile zarardaki artışın azaldığı görülmektedir. 


\section{The Journal of Accounting and Finance- August 2021 Special Issue $\quad$ 149-168}

Tablo 3. İlaç Sektöründeki İşletmelerin Kar veya Zarar ve Diğer Kapsamlı Gelir Tablosu Kalemlerinin Karşışstırılması (BİN TL)

\begin{tabular}{|c|c|c|c|c|c|c|}
\hline & 30.06.2019 & 30.06.2020 & Yüzde Değişim & 30.09.2019 & 30.09 .2020 & Yüzde Değişim \\
\hline Hasilat & 9.539 .708 & 11.553 .790 & $21,11 \%$ & 14.531 .697 & 17.418 .907 & $19,87 \%$ \\
\hline Brüt Kar/Zarar & 1.367 .557 & 1.479 .831 & $8,21 \%$ & 1.919 .600 & 2.135 .379 & $11,24 \%$ \\
\hline Personel Giderleri & 357.300 & 414.353 & $15,97 \%$ & 537.229 & 608.504 & $13,27 \%$ \\
\hline Finansman Giderleri & 126.574 & 131.354 & $3,78 \%$ & 127.795 & 179.656 & $40,58 \%$ \\
\hline Faaliyetlerden Elde Edilen Vergi Öncesi Kar & 701.816 & 994.123 & $41,65 \%$ & 1.058 .802 & 1.490 .844 & $40,80 \%$ \\
\hline Dönem Vergi Gideri & -137.114 & -137.643 & $-0,39 \%$ & -175.037 & -195.686 & $-11,80 \%$ \\
\hline Ertelenmiş Vergi Geliri/Gideri & 17.699 & -963 & $-105,44 \%$ & 10.888 & 11.363 & $4,36 \%$ \\
\hline Yabancı Para Çevrim Farkları & 11.605 & 11.789 & $1,59 \%$ & 10.495 & 4.172 & $-60,25 \%$ \\
\hline Diğer Kapsamlı Gelir & -2.497 & -41.716 & $-1570,64 \%$ & -6.451 & -40.605 & $-529,44 \%$ \\
\hline Toplam Kapsamlı Gelir & 690.915 & 814.764 & $17,93 \%$ & 877.314 & 1.254 .552 & $43,00 \%$ \\
\hline Net Dönem Kar/Zarar & 693.415 & 856.460 & $23,51 \%$ & 883.761 & 1.295 .155 & $46,55 \%$ \\
\hline
\end{tabular}

Tablo 4. Havacılık Sektöründeki İşletmelerin Kar veya Zarar ve Diğer Kapsamlı Gelir Tablosu Kalemlerinin Karşılaştırılması (BİN TL)

\begin{tabular}{|c|c|c|c|c|c|c|}
\hline & 30.06.2019 & 30.06 .2020 & Yüzde Değişim & 30.09 .2019 & 30.09 .2020 & Yüzde Değişim \\
\hline Hasilat & 40.066 .689 & 24.548 .590 & $-38,73 \%$ & 68.359 .262 & 37.770 .966 & $-44,75 \%$ \\
\hline Brüt Kar/Zarar & 5.473 .220 & -720.109 & $-113,16 \%$ & 14.217 .323 & 382.088 & $-97,31 \%$ \\
\hline Personel Giderleri & 6.471 .201 & 4.329 .690 & $-33,09 \%$ & 10.029 .237 & 6.074 .075 & $-39,44 \%$ \\
\hline Finansman Giderleri & 2.016 .276 & 2.685 .830 & $33,21 \%$ & 2.510 .801 & 5.546 .828 & $120,92 \%$ \\
\hline Faaliyet Giderleri & 5.770 .706 & 3.945 .661 & $-31,63 \%$ & 8.700 .433 & 5.447 .174 & $-37,39 \%$ \\
\hline Yolcu Hizmet ve İkram Giderleri & 1.722 .104 & 907.328 & $-47,31 \%$ & 2.732 .936 & 1.189 .231 & $-56,49 \%$ \\
\hline Akaryakıt Giderleri & 11.803 .952 & 6.819 .918 & $-42,22 \%$ & 18.740 .192 & 9.584 .107 & $-48,86 \%$ \\
\hline Faaliyetlerden Elde Edilen Vergi Öncesi Kar & -1.449 .482 & -6.616 .508 & $-356,47 \%$ & 5.041 .510 & -8.556 .692 & $-269,72 \%$ \\
\hline Dönem Vergi Gideri & -78.097 & -44.129 & $43,49 \%$ & -209.774 & -112.174 & $46,53 \%$ \\
\hline Ertelenmiş Vergi Geliri/Gideri & 619.706 & 32.010 & $-94,83 \%$ & -281.258 & 761.318 & $370,68 \%$ \\
\hline Ertelenmiş Vergi Varlıkları/Yükümlülükleri & -6.710 .664 & -9.324 .254 & $-38,95 \%$ & -7.294 .994 & -10.115 .323 & $-38,66 \%$ \\
\hline Diğer Kapsamlı Gelir & 3.990 .736 & 6.085 .236 & $52,48 \%$ & 4.013 .015 & 12.631 .407 & $214,76 \%$ \\
\hline Toplam Kapsamlı Gelir & 3.378 .023 & -566.535 & $-116,77 \%$ & 8.891 .185 & 4.690 .622 & $-47,24 \%$ \\
\hline Net Dönem Kar/Zarar & -620.704 & -6.656 .392 & $-972,39 \%$ & 4.847 .441 & -7.943 .861 & $-263,88 \%$ \\
\hline
\end{tabular}


Dönem vergi gideri kalemi 2020 yılı ikinci ve üçüncü çeyrek ara döneminde yaklaşık ortalama \%44 oranında artış göstermiştir. Ertelenmiş vergi geliri/gideri kalemi ise 30.06.2020'de \%94,83 oranında azalmış, 30.09.2020'de ise \%370,63 oranında artmıştır. Covid 19 nedeni ile sektörde yer alan bir şirket ertelenmiş vergilerin geri kazanılabilirliğini yeniden değerlendirmiş ve hesaplama sonucu ertelenmiş vergi geliri azaltıcı etki tespit etmiştir. Diğer iki şirketin 2020 yılı ikinci ve üçüncü çeyrek ara dönem finansal raporlarında herhangi bir dipnot açıklaması mevcut değildir.

Havacılık sektöründe yer alan işletmelerin 30.06.2020 tarihinde sona eren hesap döneminde Diğer kapsamlı gelir kaleminin 30.09.2020'deki artışı dikkat çekicidir. Bu artış yabancı para çevrim farklarının ve nakit akış riskinden korunma kayıplarının/kazançların artmasından kaynaklanmıştır. $\mathrm{Bu}$ durum dipnotlarda açıklanmış ancak pandeminin etkisi olarak ele alınmamıştır. Toplam kapsamlı gelir kalemi her iki dönemde de azalmıştır. Bu değişimin temel nedeni ana ortaklık paylarındaki azalıştır.

Beklentilere paralel olarak BİST 100'de havacıllk sektöründe yer alan işletmelerin dönem net kar/zarar kalemi kısıtlamaların etkisinin yansıtıldığı 2020 ikinci çeyrekte \%972,39 oranında ve kısıtlamaların kaldırılmasının etkisinin yansıtıldığı 2020 üçüncü çeyrekte ise \%263,88 oranlarında azalmıştır. Kısıtlamaların kaldırılması ile 30.09.2020'de Dönem Net Zararındaki artış azalmıştır.

\section{DEĞERLENDİRME VE SONUÇ}

Çalışmada, Covid-19'un ara dönem finansal raporlama üzerindeki etkilerini ortaya koymak ve salgın nedeniyle finansal tablolara ve dipnotlara eklenen bilgilerin değerlendirilmesi amaçlanmıştır. Bu amaçla araştırmamıza BİST 100 endeksindeki havacılık sektörü olumsuz etkilenen sektör, ilaç sektörü ise olumlu etkilenen olarak dahil edilmiştir. Bu sektörlerde faaliyet gösteren üçer işletmenin Haziran - Eylül 2019 ve 2020 ara dönem finansal raporları karşılaştırılmıştır. Bu karşılaştırılma yapılırken küresel salgın nedeniyle etkilenmesi muhtemel kalemler, yeni eklenen bilgiler ve Covid-19'a ilişkin devlet teşvikleri dikkate alınmış, işletmelerin dipnot bilgilerinde yer alan açıklamalar özetlenmiştir. Ara dönem finansal tabloların incelenmesi sonucunda dikkat çeken hususlar şunlardır:

- Hem ilaç hem de havacılık sektöründe yer alan işletmeler 2020 y1lı ikinci ve üçüncü çeyreğinde önceki yılın aynı dönemine göre nakit ve nakit benzerlerini arttırarak nakitte kalmayı tercih etmişlerdir. İlaç sektöründeki şirketler nakit ve nakit benzerlerini arttırmak için kısa vadeli borçlanma, havacılık sektöründeki şirketler ise ticari kredilerine ilişkin anapara ve faiz ödemelerini ve bazı uzun dönem sözleşmelere (akaryakıt ve kiralama gibi) ilişkin ödemeleri ertelemeye ve kısa vadeli banka kredisi kullanma yolunu tercih etmişlerdir. Covid 19'un sebep olduğu belirsizlik nedeni ile alınan bu önlemler ilaç sektöründeki şirketlerin ilgili ara dönem finansal tablo dipnotlarında belirtilmemişken, havacılık sektöründe bu konuyla ilgili dipnot açıklamalarının bulunması dikkat çekicidir.

- $\quad$ İlaç sektöründeki şirketler salgın nedeniyle şüpheli ticari alacak riskini asgariye indirgemeyi amaçlamışlar, eczanelere tanınan opsiyonlardaki artıştan kaynaklandığı için vadesi geçmiş alacaklara karşılık ayırmamışlar, bu durumu dipnotlarda açıklamışlardır. Havacılık sektöründe yer alan bir işletme ise IFRS 9'a istinaden ticari alacaklara ilişkin 
beklenen kredi karşıllğı hesaplamasında yer alan tarihi zarar oranlarının salgına dair geleceğe yönelik bilgileri de yansıtacak şekilde güncellediğini dipnotlarında belirtmiştir.

- $\quad$ Covid 19'un neden olduğu belirsizlik nedeniyle, havacillk sektöründeki işletmeler özellikle akaryakıt riskinden korunmak amacıyla faiz oranı ve döviz işlemlerini kapsayan riskten korunma araçlarına başvurmuşlardır. İlaç sektöründe yer alan sadece bir işletme satın alma hakkı olarak türev araçlarından yararlanmıştır.

- Havacılık sektöründe önemli bir kalem olan kullanım hakkı varlıkları ilaç sektörüne göre daha fazla artmıştır. Bu sektöründeki bir işletme her iki ara dönem finansal tablolarında pandemi nedeniyle filo ve kullanım hakkı varlıklarını yeniden gözden geçirdiğini ve değer düşüklüğü testleri uyguladığını, filo ve kullanım hakkı varlıkları için değer düşüklüğü tespit edemediğini belirtmiştir.

- İlaç sektöründe yer alan üç işletmeden ikisi ilgili ara dönem finansal tablolarında salgının etkilerini “Cari Döneme İlişkin Önemli Değişiklikler” başlığı altındaki dipnotlarında belirtmişlerdir. Yatırım harcamaları, operasyonel giderler ve stoklardaki artışın olumsuz etkilerini en düşük seviyede tutmak için önlemler alındığını, finansal tabloların hazırlanmasında kullanılan tahmin ve varsayımlar gözden geçirildiğini, stoklar ile maddi ve maddi olmayan duran varlıkların değerlerinde meydana gelebilecek muhtemel değer düşüklüklerinin test edildiğini ve herhangi bir değer düşüklüğü tespit edilmediğini vurgulamışlardır.

- Havacılık sektöründeki şirketler ise dipnotlarında Covid 19 nedeniyle alınan önlemlerden, devlet teşviklerinden, kapasite durumlarından, yeniden değerlendirilen kalemlerden ayrıntılı olarak bahsetmişlerdir. Hükümetin sağladığı kısa dönem çalışma ödeneğinden faydalanılması, bilet fiyatlarında üç ay süreyle KDV oranının \%18'den \%1'e indirilmesi, tahakkuk eden üç aylık KDV ve SGK prim ödemelerinde yapılan erteleme dipnotlarda yer alan bilgilerdir.

- İlaç sektöründe Brüt Satış Karının, satış maliyetlerindeki artış nedeniyle, hasılata göre daha az arttığı görülmektedir. Ayrıca salgın sebebiyle sağlık kurum ve kuruluşlarında tanıtım faaliyetlerine ara verilmesi pazarlama, satış ve dağıtım bölümündeki personel giderlerinin azalmasına neden olmuştur. Havacılık sektöründe ise yolcu taşımacılığının durdurulduğu dönemde dönem net zararın daha fazla olduğu, kısıtlamalarının kaldırılması ile zarardaki artışın azaldığı görülmektedir. Ayrıca faaliyet giderleri, yakıt, konma ve konaklama, üstgeçit ve yolcu ikram giderlerindeki önemli azalış sektörün daha fazla zarar etmesini engelleyen unsurlar olarak karşımıza çıkmaktadır.

- Havacılık sektöründe salgın nedeniyle yolcu taşımacılığının azaldığı kargo taşımacılığının ise neredeyse iki katına çıktığı görülmektedir. $\mathrm{Bu}$ da sektörün küresel pandemi krizinin etkilerini olabildiğince az zararla atlatmasını kolaylaştırmıştır.

- İlaç sektöründe dönem karının artığı ve bunun nedeni hasılatın "esas faaliyetlerden diğer gelirlerin ve yatırım faaliyeti gelirlerinin artmasından" kaynaklandığ görülmüştür. Diğer taraftan dönem vergi giderinde dikkat çekici bir artış gerçekleşmemiştir. Bunun nedeni teşvik kapsamındaki harcamalarda muhtelif vergi avantajlarının bulunmasıdır.

Salgının etkileri üzerine yapılacak kapsamlı dipnot açıklamaları, Covid-19'a karşı alınan ekonomik önlemleri de içermelidir. Böylece muhasebe bilgi kullanıcıları işletmelerle ilgili tam bilgi sahibi olurlar. Bilindiği gibi ülkemizde alınan ekonomik önlemler arasında kısa çalışma ödeneği, devlet teşvikleri - vergi ertelemeleri, KDV oranlarında indirim, kredi ertelemeleri yer almaktadır. 
Araştırmamızın çıkış noktası çalışmamızın, küresel salgın döneminde Covid 19'un ara dönem finansal tablolara olası etkileri başlığında açıklanan maddelere ilişkin dipnotlarda daha fazla bilgi paylaşımında bulunacağı yönündeydi. Ancak bu konularla ilgili beklenen açıklamaların dipnot bilgilerinde özellikle ilaç sektöründe yeterli düzeyde olmadığ görülmüştür. $\mathrm{Bu}$ durum finansal bilgi kullanıcılarının gereksinim duydukları bilgileri tüm yönleriyle elde edememesine neden olacak, diğer finansal ve finansal olmayan bilgilerin bulunduğu faaliyet raporları, entegre raporlar, meslek örgüt ve kuruluşlarının yayınları gibi ek bilgilere ihtiyaç duyacaklardır.

\section{KAYNAKLAR}

Boydaş Hazar, Hülya (2020), "Türkiye Muhasebe Standartları Açısından Finansal Tabloların Hazırlanmasında Covid-19 Salgınının Etkisi”, Turkish Studies - Economy Dergisi, 15(4), ss.2101-2115.

Cavlak, Hakan (2020), “Covid-19 Pandemisinin Finansal Raporlama Üzerindeki Olası Etkileri: BİST 100 Endeksi’ndeki İşletmelerin Ara Dönem Finansal Raporlarının İncelenmesi”, Gaziantep Üniversitesi Sosyal Bilimler Dergisi, S.19(COVID-19 Special Issue), ss.143-168.

Deloitte (2020), “Covid-19’un işletmelere olan finansal etkileri ve çözüm önerileri. Financial

Advisory”, https:/www2.deloitte.com/content/dam/Deloitte/tr/Documents/financialadvisory/COVID-19-un-isletmelere-olan-finansal-etkileri.pdf (06.02.2021)

Demir, Zekeriya (2020), “Covid-19'un TFRS Kapsamındaki Finansal Raporlamaya Olan Etkileri ve TMS Kapsamında Denetçinin Dikkate Alması Gereken Hususların Değerlendirilmesi”, Muhasebe ve Denetime Bakış, S.21(61), ss.255-278.

Ernst \& Young (2020), “Applying IFRS Accounting Considerations of the Coronavirus Outbreak”, https://www.ey.com/en_gl/ifrs-technical-resources/accountingconsiderations-of-the-coronavirus-pandemic-updated-november-2020 (06.02.2021)

Europeen Securities and Markets Authority -ESMA (2020), "ESMA Calls for Transparency on COVID-19 Effects in Half-yearly Financial Reports”, https://www.esma.europa.eu/press-news/esma-news/esma-calls-transparency-covid19-effects-in-half-yearly-financial-reports (06.02.2021)

GrantThornton (2020), “COVID-19 Salgınının Finansal Raporlama Etkileri”, https://www.grantthornton.com.tr/globalassets/1.-member-firms/turkey/ifrsyaynlar/covid-19_sfretkileri.pdf (10.02.2021)

International Accounting Standards Board -IASB (2020), “Applying IFRS Standards in 2020 - Impact of Covid-19”, https://www.ifrs.org/news-and-events/2020/10/applying-ifrsstandards-in-2020-impact-of-covid-19/ (06.02.2021)

International Federation of Accountants- IFAC (2020), https://www.ifac.org/knowledgegateway/supporting-international-standards/discussion/financial-reportingimplications-covid-19 (06.02.2021) 
İSMMMO (2020), "Koronavirüsün (Covid-19) Finansal Tablolar ve Bağımsız Denetim Çalışmaları Üzerine Muhtemel Etkileri”, https://archive.ismmmo.org.tr/YAYINLAR/e_kitap/31032020_bulten.pdf

Jabbar, A. K.- Almayyahı, A. R. A., Alı, I. M., - Alnoor, A. (2020), "Mitigating Uncertainty in the Boardroom: Analysis to Financial Reporting for Financial Risk COVID-19”, The Journal of Asian Finance, Economics and Business, 7(12), pp. 233-243.

Karacan, Sami (2020), “Yeni Tip Koronavirüs’ün (COVID-19) Finansal Tablolara Muhtemel Etkileri”, Uluslararası Sosyal Araştırmalar Dergisi, 13 (73), Ekim, ss.944-951.

KGK (2020), TMS 8 "Muhasebe Politikaları, Muhasebe Tahminlerinde Değişiklikler Ve Hatalar”Standard1,https://kgk.gov.tr/Portalv2Uploads/files/Duyurular/v2/TMS/TMS_2 020/TMS\%208.pdf (10.02.2021)

KGK (2020), TMS 34 “Ara Dönem Finansal Raporlama" Standard1, https://kgk.gov.tr/Portalv2Uploads/files/Duyurular/v2/TMS/TMS_2020/TMS\%2034.p df (10.02.2021).

KPMG (2020), “Covid-19 Finansal Raporlama Üzerindeki Potansiyel Etkileri”, https://assets.kpmg/content/dam/kpmg/tr/pdf/2020/04/covid19-finansal-raporlamauzerindeki-potansiyel-etkileri.pdf (10.02.2021)

PWC (2020), "Korona Virüsünün Muhasebe Uygulamalarına Etkisi”, Uluslararası Finansal Raporlama Standartları Bülteni, https://www.pwc.com.tr/tr/Hizmetlerimiz/denetim/ufrs-tfrs-raporlamasi/finansalraporlama-standarti-tfrs-mart-2020.pdf (10.02.2021)

Savova, Kameliya (2021), "Global Impact of COVID 19 on the Concept of 'Going Concern'”, Globalization and its Socio-Economic Consequences SHS Web of Conferences 92, 010, EDP Sciences.

TÜRMOB (2020), “Koronavirüs krizi: Finansal Raporlama ve Denetim Üzerindeki Sonuçları”,https://www.turmob.org.tr/ebulten/TURMOBHaber/52/files/assets/commo n/downloads/52.pdf (10.02.2021) 